\title{
Thermal Environment and Acid-Base Homeostasis in Human Infants during the First Few Hours of Life *
}

\author{
G. M. Gandy, K. Adamsons, Jr., $\dagger$ N. Cunningham, $\ddagger$ W. A. Silverman, and \\ L. S. JAMES $\S$ \\ (From the Departments of Anesthesiology, Obstetrics and Gynecology, and Pediatrics of the \\ College of Physicians \& Surgeons, Columbia University, and from the Divisions \\ of Anesthesiology, Obstetrics and Gynecology [Sloane Hospital], and \\ Pediatrics [Babies Hospital] of the Presbyterian Hospital, \\ New York, N.Y.)
}

It has recently been shown that labor and delivery result in variable degrees of respiratory and metabolic acidosis in the human infant (1). With the prompt establishment of effective ventilation, the healthy newborn achieves a relatively normal acid-base state in the first few hours of life (2). The optimal thermal environment for this recovery is unknown.

It is generally accepted that the newborn infant is a true homeotherm from the time of birth. Consequently, it is reasonable to suppose that the increased metabolism in a cool environment might lead to an accumulation of lactic, pyruvic, and other organic acids, thereby aggravating the existing acidosis. This would be particularly true if metabolic needs were to exceed oxygen availability to the tissues. Conversely, it could be proposed that the cool environment might favorably influence the acid-base homeostasis if the formation of acid metabolites were reduced at a lower body temperature.

With these possibilties in mind a study was designed to explore the relationship between acid-base status and thermal environment in the first hours of life. It was hoped that such information would contribute to our understanding of the optimal environmental temperature for the newborn.

* Submitted for publication October 3, 1963; accepted December 19, 1963.

This research was supported by U. S. Public Health Service grants RG 9069 and A-4359.

$\dagger$ Senior Wellcome research fellow.

¥ National Institutes of Health postdoctoral fellow.

$\S$ Recipient of Investigatorship of the Health $\mathrm{Re}$ search Council of the City of New York under contract I-148. Present address: Presbyterian Hospital, 622 West 168th St., New York 32, N. Y.

\section{Methods}

In an initial series of observations, 24 healthy fullterm infants from the obstetric service of the Sloane Hospital were studied. The infants were divided into two groups, "warm" and "cool." Each of these two groups consisted of six infants delivered by elective Cesarean section and six delivered vaginally. The two groups were considered comparable in regard to premedication, anesthesia, birth weight, and Apgar score ${ }^{1}$ (3) at 1 minute (see Table I). All vaginal deliveries were uncomplicated, being either spontaneous or by low forceps.

The environment to which a particular infant was assigned was determined before delivery by a random permutation of numbers in groups of four. The period of observation was continued for approximately 2 hours from the time of birth. In the warm group deep rectal temperature was maintained at approximately $37.0^{\circ} \mathrm{C}$ by placing the infant immediately after birth under a thermostatically controlled radiant heating device. $^{2}$ They were left exposed to the radiant heat except when draping was necessary for obtaining blood samples. Infants in the "cool" group were left uncovered at room temperature (mean, $25.0^{\circ} \mathrm{C}$; range, 22.5 to $26.5^{\circ} \mathrm{C}$ ). Temperatures in all infants were monitored continuously by thermistor probes and a multichannel polygraph. Thermistors were placed in the rectum ( $8 \mathrm{~cm}$ from anus), on the skin of the anterior abdominal wall, and in the room air. In the warm group the skin thermistor was shielded from the direct heating of the infrared lamp.

1 Apgar scoring system. This provides objective means of evaluating the over-all condition of a newborn infant. It consists of assigning a score of 0,1 , or 2 to each of five criteria, namely heart rate, respiratory performance, reflex irritability, muscle tone, and color. The score is recorded routinely at 1 minute of age. Under this system, infants who score 7 or higher are classed as being in good condition, those who score between 4 and 6 are moderately depressed, and those whose score falls between 0 and 3 are severely depressed.

2 Experimental model made by Airshields, Inc., Hatboro, $\mathrm{Pa}$. 
TABLE I

Summary of clinical data in 24 infants*

\begin{tabular}{|c|c|c|c|c|c|c|c|c|}
\hline \multicolumn{2}{|l|}{ Group } & $\underset{\text { wt }}{\text { Birth }}$ & $\begin{array}{c}\text { Apgar } \\
\text { score }\end{array}$ & Pregnancy & Medication & Anesthesia & Delivery & Complication \\
\hline & & $\mathrm{kg}$ & $1 \min$ & & $\begin{array}{c}m g \\
\text { Demerol } 75\end{array}$ & & & \\
\hline \multirow[t]{12}{*}{ Warm } & VV & 3.3 & 5 & Normal & Demerol 75 & $\mathrm{~N}_{2} \mathrm{O}$ & $\mathrm{LF}$ & Nuchal cord \\
\hline & & 3.2 & 7 & Normal & 0 & Caudal and $\mathrm{N}_{2} \mathrm{O}$ & $\mathrm{LF}$ & None \\
\hline & & 3.1 & 7 & Normal & Demerol 25 & Caudal and $\mathrm{N}_{2} \mathrm{O}$ & LF & None \\
\hline & & 2.7 & 8 & Normal & Demerol 50 & $\mathrm{~N}_{2} \mathrm{O}$ & NSD & None \\
\hline & & 3.4 & 7 & Normal & 0 & Saddle block & NSD & None \\
\hline & & 2.6 & 6 & Normal & Demerol 75 & Caudal and $\mathrm{N}_{2} \mathrm{O}$ & NSD & None \\
\hline & $\mathrm{CS}$ & 3.0 & 8 & Normal & $\begin{array}{l}\text { Atropine } 0.4 \\
\text { Demerol } 50\end{array}$ & Spinal & Elective CS & None \\
\hline & & 4.7 & 7 & Normal & $\begin{array}{l}\text { Atropine } 0.4 \\
\text { Demerol } 50\end{array}$ & Spinal & Elective CS & None \\
\hline & & 3.5 & 8 & $\begin{array}{l}\text { Mild } \\
\text { toxemia }\end{array}$ & $\begin{array}{l}\text { Atropine } 0.4 \\
\text { Demerol } 50\end{array}$ & Spinal & $\mathrm{CS}$ & None \\
\hline & & 2.7 & 8 & Normal & $\begin{array}{l}\text { Atropine } 0.4 \\
\text { Demerol } 50\end{array}$ & Spinal & Elective CS & None \\
\hline & & 3.0 & 8 & Normal & $\begin{array}{l}\text { Atropine } 0.4 \\
\text { Demerol } 50\end{array}$ & Spinal & Elective CS & None \\
\hline & & 3.3 & 9 & Normal & $\begin{array}{l}\text { Atropine } 0.4 \\
\text { Demerol } 50\end{array}$ & Spinal & Elective CS & None \\
\hline \multirow[t]{11}{*}{ Cool } & VV & 3.0 & 9 & Normal & Seconal 100 & $\mathrm{~N}_{2} \mathrm{O}$ & $\mathrm{LF}$ & None \\
\hline & & 2.5 & 8 & Normal & Demerol 75 & $\mathrm{~N}_{2} \mathrm{O}$ & LF & None \\
\hline & & 3.3 & 6 & Normal & Demerol 75 & Epidural & LF & None \\
\hline & & 3.2 & 8 & Normal & 0 & Caudal & NSD & None \\
\hline & & $\begin{array}{l}3.2 \\
3.2\end{array}$ & $\begin{array}{l}8 \\
8\end{array}$ & $\begin{array}{l}\text { Normal } \\
\text { Normal }\end{array}$ & $\begin{array}{l}0 \\
0\end{array}$ & $\begin{array}{l}\text { Caudal } \\
\mathrm{N}_{2} \mathrm{O}\end{array}$ & $\begin{array}{l}\text { NSD } \\
\text { NSD }\end{array}$ & $\begin{array}{l}\text { None } \\
\text { None }\end{array}$ \\
\hline & $\mathrm{CS}$ & 3.0 & 7 & Normal & $\begin{array}{l}\text { Atropine } 0.4 \\
\text { Demerol } 50\end{array}$ & $\begin{array}{l}\text { Thiopental, } \\
\text { Succinylcholine, } \mathrm{N}_{2} \mathrm{O}\end{array}$ & Elective CS & None \\
\hline & & 3.6 & 8 & Normal & $\begin{array}{l}\text { Atropine } 0.4 \\
\text { Demerol } 50\end{array}$ & $\begin{array}{l}\text { Thiopental, } \\
\text { Succinylcholine, } \mathrm{N}_{2} \mathrm{O}\end{array}$ & Elective CS & None \\
\hline & & 2.7 & 9 & Normal & $\begin{array}{l}\text { Atropine } 0.4 \\
\text { Demerol } 50\end{array}$ & $\begin{array}{l}\text { Thiopental, } \\
\text { Succinylcholine, } \mathrm{N}_{2} \mathrm{O}\end{array}$ & Elective CS & None \\
\hline & & 3.0 & 7 & Normal & $\begin{array}{l}\text { Atropine } 0.4 \\
\text { Demerol } 50\end{array}$ & Spinal & Elective CS & None \\
\hline & & 2.4 & 8 & Normal & $\begin{array}{l}\text { Atropine } \mathbf{0 . 4} \\
\text { Demerol } \mathbf{5 0}\end{array}$ & Spinal & Elective CS & None \\
\hline & & 3.2 & 7 & Normal & $\begin{array}{l}\text { Atropine } 0.4 \\
\text { Demerol } 50\end{array}$ & Spinal & Elective CS & None \\
\hline
\end{tabular}

$* \mathrm{VV}=$ vaginal vertex $; \mathrm{CS}=$ Cesarean section $; \mathrm{LF}=$ low forceps $; \mathrm{NSD}=$ normal spontaneous delivery.

Initial blood samples were taken from the artery of a doubly clamped segment of the umbilical cord. Subsequent specimens were obtained either by direct needle puncture of the femoral artery or by catheterization of the umbilical artery. The samples were drawn into greased, heparinized syringes and stored in iced water. A certain number of the acid-base determinations were done on "arterialized" capillary blood, since results from this laboratory have shown a good correlation between arterial blood and that obtained from a heel prick, provided the extremity is adequately warmed for 10 minutes and precautions are taken to prevent the loss of $\mathrm{CO}_{2}$. All determinations were done within 30 minutes of taking the sample.
Hydrogen ion activity of whole blood was determined using the radiometer microglass electrode (4). Buffer base (B.B.), base excess (B.E.), ${ }^{3}$ total $\mathrm{CO}_{2}$, and $\mathrm{CO}_{2}$ tension $\left(\mathrm{PCO}_{2}\right)$ were calculated from $\mathrm{pH}$ measurements

${ }^{3}$ Base excess, a term recently introduced by Astrup, Andersen, J $\phi$ rgensen, and Engel (5), represents the amount of fixed acid or base in milliequivalents per liter required to restore the $\mathrm{pH}$ of a blood sample to 7.38 at $38^{\circ} \mathrm{C}$ and at a $\mathrm{PCO}_{2}$ or $40 \mathrm{~mm} \mathrm{Hg}$. By definition the normal value is zero. Since a negative value for base excess is somewhat confusing, we have elected to use the term base deficit. Thus base excess connotes metabolic alkalosis and base deficit, metabolic acidosis. 
of blood equilibrated at two known $\mathrm{CO}_{2}$ tensions according to the method described by Astrup, Siggaard Andersen, J $\phi$ rgensen, and Engel (5) and Siggaard Andersen and Engel (6). As all pH determinations were done at $38^{\circ} \mathrm{C}$, the obtained values were corrected for differences in temperature by the Rosenthal factor of $0.0147 \mathrm{pH}$ per degree C (7). Similarly, corrections were made for $\mathrm{PCO}_{2}$ by using the factor of $4.4 \%$ per $1^{\circ} \mathrm{C}$ given by Bradley, Stupfel, and Severinghaus (8). It was arbitrarily decided to use the babies' deep rectal temperature to calculate the above corrections.

The mean $\mathrm{pH}$ was computed from individual $\mathrm{pH}$ values after converting them into microequivalents of hydrogen ion per liter. Over the rather narrow $\mathrm{pH}$ range these means did not differ significantly from the arithmetic means of the numerical $\mathrm{pH}$ values.

Buffer base and base excess were determined on all samples at full oxygen saturation; however, only base excess or base deficit values are referred to in the results section, because buffer base, unlike base excess, is dependent upon the hemoglobin concentration (9). This latter determination was not carried out on all samples.

Similar observations were made on eight healthy and four depressed full-term infants, in whom measurements of oxygen consumption as well as acid-base state were obtained under both warm and cool conditions. The healthy infants all had an Apgar score of 7 or higher at 1 minute, whereas the depressed group scored $1,2,2$, and 6 , respectively. All of the latter infants responded promptly to resuscitation, and their subsequent nursery progress was uneventful. These infants were placed as soon as possible after delivery, usually within 15 minutes, into a double-walled box which was in series with a closed circuit for measurement of oxygen consumption. Air was circulated at a constant temperature (approximately $\left.34^{\circ} \mathrm{C}\right)$. Radiant heat loss was prevented by circulating water at $37^{\circ} \mathrm{C}$ through the double wall of the box. In this way the infants' rectal and skin temperatures were maintained at about $37^{\circ} \mathrm{C}$. After a period of at least 2 hours under these conditions during which time the healthy infants achieved a relatively normal acid-base status, blood samples were obtained. The temperature in the circuit was then reduced to approximately $23^{\circ} \mathrm{C}$. When the circuit temperature had equilibrated, the infant's oxygen consumption was again measured. This mild cold stress was maintained for approximately 60 minutes, after which further blood samples were obtained.

The samples were analyzed for $\mathrm{pH}, \mathrm{PCO}_{2}, \mathrm{CO}_{2}$ content, and base deficit. In most cases, lactate and pyruvate levels were determined by modifications of the methods of Barker and Summerson for lactate (10) and Friedemann and Haugen for pyruvate (11).

\section{Results}

These will be presented in two sections, the first dealing with the 24 healthy infants randomly asigned either to a "warm" or "cool" environment and the second dealing with the infants studied under both thermal conditions.

\section{Section I}

The results were analyzed in two stages, first by comparing the effect of the mode of delivery within both warm and cool groups and secondly by comparing the effect of environmental temperature. It was established by the $t$ test that

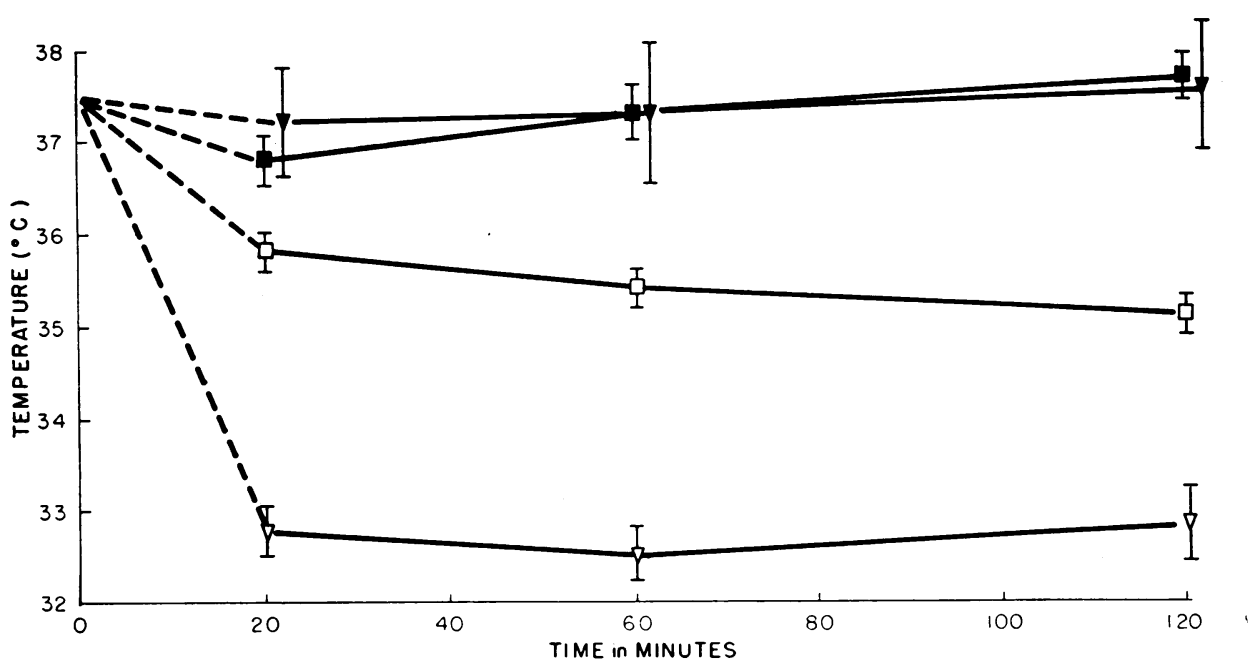

Fig. 1. Mean Rectal and SKin temperatures in 24 infants at two different enVIRONMENTAL TEMPERATURES DURING THE FIRST 2 HOURS OF LIFE. Temperature at birth is assumed to be $37.5^{\circ} \mathrm{C}$. Measurements were not obtained in all infants. $\square=$ rectal temperature, $\nabla=$ skin temperature-cool; $\mathbf{\square}=$ rectal temperature, $\nabla=$ skin temperaturewarm. Vertical bars represent $\pm 1 \mathrm{SE}$ of the mean. 


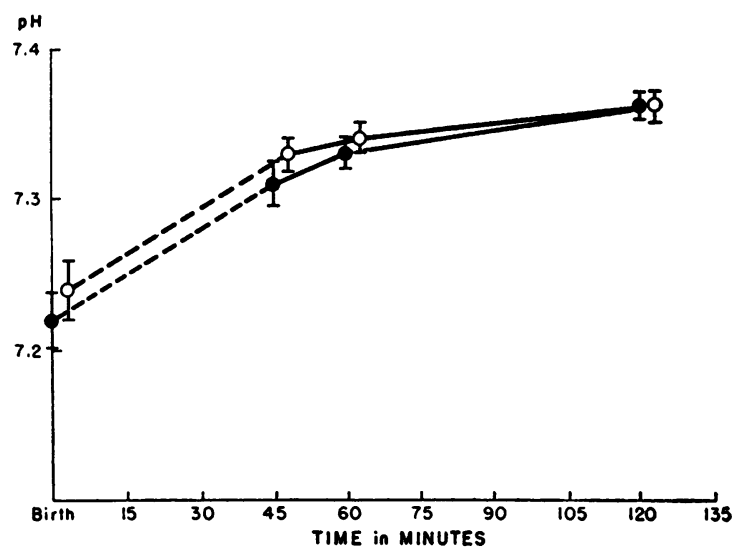

Fig. 2. Mean pH values of 24 infants at two DIFFERENT ENVIRONMENTAL TEMPERATURES DURING THE FIRST 2 HOURS OF LIFE. $O=\mathrm{cool} ; 0=$ warm. Vertical bars represent $1 \mathrm{SE}$ of the mean.

there were no significant differences between infants delivered by Cesarean section and those born vaginally either at birth or subsequently. Therefore, the values obtained within each temperature group were combined and the "warm" group compared with the "cool" by the $t$ test.

Temperature. In the warm group the mean rectal and skin temperatures were maintained at approximately 37 to $37.5^{\circ} \mathrm{C}$ (Figure 1 ). In the cool group there was a pronounced fall in skin as well as deep body temperature after delivery, the fall having the characteristics of an exponential function. In the initial 15 minutes after birth the skin temperature fell almost $4^{\circ} \mathrm{C}$. Dur-

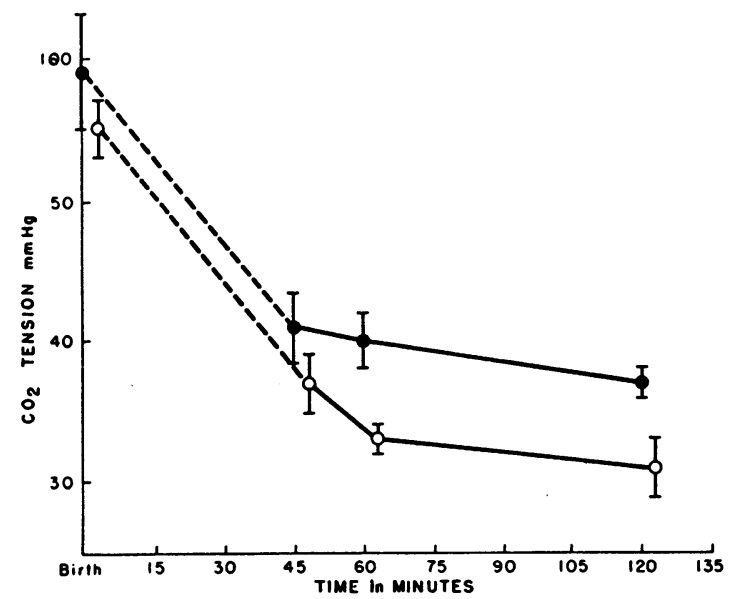

Fig. 3. Mean $\mathrm{CO}_{2}$ tension of 24 infants at two DIFFERENT ENVIRONMENTAL TEMPERATURES DURING THE FIRST 2 hOURS OF LIFE. Symbols same as Figure 2. ing the ensuing 45 minutes a further drop of about $0.5^{\circ} \mathrm{C}$ occurred, the temperature finally leveling at approximately $33^{\circ} \mathrm{C}$ after the first hour. The rectal temperature reached approximately $35^{\circ} \mathrm{C}$ after 2 hours. From the age of 15 minutes, there was a temperature gradient of 2.5 to $3^{\circ} \mathrm{C}$ between skin and rectum. The cooler infants were much more active than those in the warm environment. Intermittent shivering was observed, although seldom in the first 15 minutes.

Hydrogen ion activity. The rate of rise of $\mathrm{pH}$ in both warm and cool groups was similar, being fairly rapid over the first hour and more gradual over the second hour as normal values

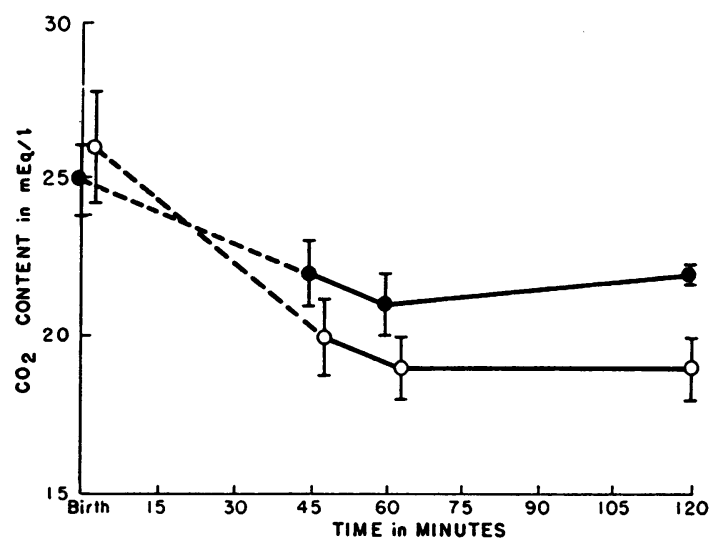

Fig. 4. Mean values for base deficit in 24 infants AT TWO DIFFERENT ENVIRONMENTAL TEMPERATURES DURING THE FIRST 2 HOURS OF LIFE. Symbols same as Figure 2 .

were approached (Figure 2). At the end of 2 hours the mean $\mathrm{pH}$ value was 7.36 in both warm and cool groups.

$\mathrm{CO}_{2}$ tension. $\mathrm{PCO}_{2}$ fell rapidly in both groups (Figure 3). However, at the end of the first hour the value in the warm group was significantly higher $(40 \mathrm{~mm} \mathrm{Hg}$ ) compared to the cool group $(33 \mathrm{~mm} \mathrm{Hg})(\mathrm{p}<0.02)$. At the end of the second hour there was still a significant difference between the two groups $(p<0.01)$, the mean value in the warm group being $37 \mathrm{~mm}$ $\mathrm{Hg}$ compared to $31 \mathrm{~mm} \mathrm{Hg}$ in the cool group.

Total $\mathrm{CO}_{2}$. The initial values in the two groups were similar, but after birth there was a small but consistent difference (Figure 4). At the end of 2 hours the mean value in the warm group was $22 \mathrm{mEq}$ per $\mathrm{L}$ as opposed to $19 \mathrm{mEq}$ 
per $\mathrm{L}$ in the cool group. The difference was statistically significant $(\mathrm{p}<0.01)$.

Base deficit. The mean values at birth were essentially identical in the two groups (Figure 5). Infants kept in the warm environment showed a steady elimination of base deficit, the mean value reaching $1.5 \mathrm{mEq}$ per $\mathrm{L}$ at the end of 2 hours. By contrast the base deficit in the cool group after 2 hours averaged $5.5 \mathrm{mEq}$ per $\mathrm{L}$, an insignificant fall during the cold exposure. The difference between the means at 1 and 2 hours was statistically significant $(p<0.01)$.

\section{Section II}

Data from eight healthy infants studied under both warm and cool conditions are summarized in Table II. The rectal and skin temperatures were maintained at approximately $37^{\circ} \mathrm{C}$ for the first 2 hours of life. During this period, the infants showed almost complete recovery from birth asphyxia. The mean $\mathrm{pH}$ rose from 7.26 to $7.35 ; \mathrm{PCO}_{2}$ fell from 58 to $39 \mathrm{~mm} \mathrm{Hg}$, and base deficit fell from 5.6 to $2.1 \mathrm{mEq}$ per L. After being placed in the cool environment $\left(23^{\circ} \mathrm{C}\right)$, where they remained for the next hour, the oxygen consumption immediately doubled. Despite this increase in metabolic rate, there was a fall in rectal temperature to a mean value of $34.2^{\circ} \mathrm{C}$. The rate of fall in temperature was gradual compared with the initial precipitous fall seen in infants placed in a cool environment at birth. During this time the $\mathrm{pH}$ remained unchanged, although there was a significant increase in base

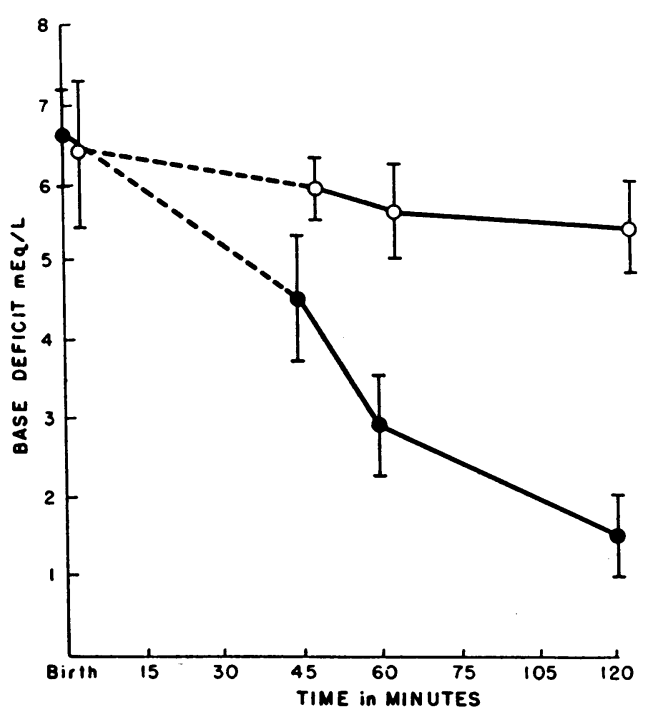

Fig. 5. Mean values for total $\mathrm{CO}_{2}$ in 24 infants AT TWO DIFFERENT ENVIRONMENTAL TEMPERATURES DURING ThE FIRST 2 hours of LIFE. Symbols same as Figure 2 .

deficit $(\mathrm{p}<0.05)$. This was accompanied by a reduction in $\mathrm{PCO}_{2}(\mathrm{p}<0.05)$ and total $\mathrm{CO}_{2}(\mathrm{p}<$ 0.01). Blood lactate rose slightly; however, the ratio of lactate to pyruvate remained unchanged in three infants and showed only a small increase in two.

Similar measurements made in four depressed infants (Table III) revealed distinct differences in behavior. Exposure to the cool environment was followed in all instances by a fall in blood $\mathrm{pH}$. This was due to a pronounced metabolic acidosis, as shown by a rise in base deficit up

TABLE II

Mean values $\pm \mathrm{SE}$ for $\mathrm{pH}, \mathrm{PCO}_{2}$, total $\mathrm{CO}_{2}$, base deficit, lactate, pyruvate, $\mathrm{O}_{2}$ consumption, and rectal temperature in eight healthy newborn infants, Apgar score 7 or higher at birth. and under warm and cool conditions

\begin{tabular}{|c|c|c|c|c|c|c|c|c|}
\hline & $\mathrm{pH}$ & $\mathrm{PcO}_{2}$ & Total $\mathrm{CO}_{2}$ & Base deficit & Lactate* & Pyruvate* & $\mathrm{O}_{2}$ consump- & $\begin{array}{l}\text { Rectal } \\
\text { temp. }\end{array}$ \\
\hline & & $m m \mathrm{Hg}$ & mmoles $/ L$ & $m E q / L$ & $m E q / L$ & $m E q / L$ & $\mathrm{ml} / \mathrm{kg} / \min$ & ${ }^{\circ} \mathrm{C}$ \\
\hline Birth & $7.26 \pm 0.020$ & $58 \pm 5$ & $27 \pm 0.5$ & $5.6 \pm 1.4$ & $4.0 \pm 0.6$ & $0.27 \pm 0.07$ & & \\
\hline $\begin{array}{l}\text { Warm, } \\
34^{\circ} \mathrm{C} \\
\text { age } 2 \text { hrs }\end{array}$ & $7.35 \pm 0.006$ & $39 \pm 2.1$ & $22 \pm 1.0$ & $2.1 \pm 1.7$ & $2.8 \pm 0.4$ & $0.27 \pm 0.04$ & $5.0 \pm 0.3$ & $37 \pm 0.2$ \\
\hline$\stackrel{\text { Cool, }}{23^{\circ} \mathrm{C}}$ & $7.35 \pm 0.013$ & $34 \pm 2.1$ & $20 \pm 0.6$ & $4.7 \pm 1.5$ & $3.4 \pm 0.5$ & $0.22 \pm 0.05$ & $10.8 \pm 0.5$ & $34.2 \pm 0.4$ \\
\hline $\begin{array}{l}\text { Mean } \\
\text { change } \\
\text { between } \\
\text { warm and } \\
\text { cool }\end{array}$ & 0 & $-4.9 \pm 1.8$ & $-2.0 \pm 0.6$ & $+2.6 \pm 0.7$ & $+0.6 \pm 0.3$ & $-0.05 \pm 0.02$ & $+5.8 \pm 1.0$ & $+2.8 \pm 0.3$ \\
\hline
\end{tabular}

* The mean values for lactate and pyruvate represent five of these eight infants. 
TABLE III

Values for $p \mathrm{H}, \mathrm{PCO}_{2}$, total $\mathrm{CO}_{2}$, base deficit, lactate, pyruvate, oxygen consumption, and rectal temperature in four infants who were depressed at birth (Apgar score 6 or less)

\begin{tabular}{|c|c|c|c|c|c|c|c|c|c|}
\hline Infant & & $\mathrm{pH}$ & $\mathrm{PcO}_{2}$ & $\begin{array}{l}\text { Total } \\
\mathrm{CO}_{2}\end{array}$ & $\begin{array}{c}\text { Base } \\
\text { deficit }\end{array}$ & Lactate & Pyruvate & $\begin{array}{c}\mathrm{O}_{2} \text { Con- } \\
\text { sumption }\end{array}$ & $\begin{array}{l}\text { Rectal } \\
\text { temp. }\end{array}$ \\
\hline $\begin{array}{l}\text { No. } 227 \\
\quad \text { Score } 6\end{array}$ & $\begin{array}{l}\text { Birth } \\
\text { Warm } \\
\text { Cool }\end{array}$ & $\begin{array}{l}7.21 \\
7.35 \\
7.31\end{array}$ & $\begin{array}{c}m m \mathrm{Hg} \\
72 \\
43 \\
37\end{array}$ & $\begin{array}{c}\text { mmoles } / L \\
30 \\
24 \\
22\end{array}$ & $\begin{array}{c}m E q / L \\
3.8 \\
0.5 \\
5.2\end{array}$ & $\begin{array}{c}m E q / L \\
5.8 \\
3.0 \\
3.1\end{array}$ & $\begin{array}{c}m E q / L \\
0.36 \\
0.22 \\
0.16\end{array}$ & $\begin{array}{c}\mathrm{ml} / \mathrm{kg} / \mathrm{min} \\
\\
5.5 \\
9.6\end{array}$ & $\begin{array}{l}37.0 \\
33.5\end{array}$ \\
\hline $\begin{array}{l}\text { No. } 232 \\
\quad \text { Score } 2\end{array}$ & $\begin{array}{l}\text { Birth } \\
\text { Warm } \\
\text { Cool }\end{array}$ & $\begin{array}{l}7.25 \\
7.34 \\
7.25\end{array}$ & $\begin{array}{l}58 \\
43 \\
39\end{array}$ & $\begin{array}{l}27 \\
24 \\
21\end{array}$ & $\begin{array}{l}6.3 \\
1.5 \\
6.1\end{array}$ & $\begin{array}{l}1.3 \\
2.3\end{array}$ & $\begin{array}{l}0.19 \\
0.20\end{array}$ & $\begin{array}{l}4.0 \\
9.0\end{array}$ & $\begin{array}{l}37.5 \\
35.0\end{array}$ \\
\hline $\begin{array}{l}\text { No. } 233 \\
\quad \text { Score } 1\end{array}$ & $\begin{array}{l}\text { Birth } \\
\text { Warm } \\
\text { Cool }\end{array}$ & $\begin{array}{l}7.08 \\
7.38 \\
7.32\end{array}$ & $\begin{array}{l}56 \\
31 \\
25\end{array}$ & $\begin{array}{l}19 \\
14\end{array}$ & $\begin{array}{r}20.0 \\
6.0 \\
11.6\end{array}$ & & & $\begin{array}{l}6.0 \\
9.5\end{array}$ & $\begin{array}{l}38.0 \\
36.0\end{array}$ \\
\hline $\begin{array}{l}\text { No. } 236 \\
\quad \text { Score } 2\end{array}$ & $\begin{array}{l}\text { Birth } \\
\text { Warm } \\
\text { Cool }\end{array}$ & $\begin{array}{l}7.35 \\
7.32\end{array}$ & $\begin{array}{l}40 \\
25\end{array}$ & $\begin{array}{l}23 \\
21\end{array}$ & $\begin{array}{r}1.6 \\
11.5\end{array}$ & $\begin{array}{l}9.1 \\
2.8 \\
4.4\end{array}$ & $\begin{array}{l}0.36 \\
0.30 \\
0.22\end{array}$ & $\begin{array}{l}5.5 \\
8.2\end{array}$ & $\begin{array}{l}38.0 \\
33.0\end{array}$ \\
\hline
\end{tabular}

to $10 \mathrm{mEq}$ per $\mathrm{L}$. There was a consistent fall in total $\mathrm{CO}_{2}$ and $\mathrm{PCO}_{2}$, although the magnitude of the change varied from infant to infant. The increase in oxygen consumption in the cool environment was generally less. Blood lactate levels rose only slightly; however, there was a considerable increase in the lactate to pyruvate ratio in all infants.

\section{Discussion}

This study has confirmed earlier observations (12) that there is a fall of body temperature after birth if the infant is kept at room temperature $\left(20\right.$ to $\left.23^{\circ} \mathrm{C}\right)$. This fall is initially extremely rapid. The two main contributing factors are evaporation of water from the body surface and lungs and a high thermal conductance. The skin temperature falls even more rapidly than the deep body (rectal) temperature. As shown by Brück, Brück, and Lemtis (13), the fall in skin temperature observed upon exposure to cold is partly due to a decrease in skin blood flow.

The fall in body temperature, however, does not imply that the newborn infant is poikilothermic. It has been shown in this and other studies (14) that the human newborn infant, in common with most mammals, is a true homeotherm, since there is an increase in metabolic rate upon exposure to a cool environment. This fall in temperature indicates therefore that in the immediate neonatal period, heat production is insufficient to make up for the heat loss.
For technical reasons it has not been possible to measure metabolic rate during the first minutes of life when the infant's temperature is falling rapidly. It may well be that thermogenesis is impaired at this time. Hypoxia and hypercapnea are known to reduce the metabolic response to cooling (15-17), and chemoreceptor stimulation may abolish shivering $(18,19)$. Since the infant is both hypoxic and hypercapnic as a result of the delivery process, it is reasonable to suppose that each of these factors could be contributing to a decreased heat production.

By the age of 2 hours thermal stability of the newborn appears to be increased as evidenced by a slower rate of fall in body temperature when the infant is subjected to a comparable cold stress. This could be due either to decreased heat loss or to improved thermogenesis. Although it is difficult to assess the relative contributions made by these two mechanisms in the neonate, from thermodynamic considerations the former should play the more important role.

Despite a difference in deep body temperature between the two groups of infants in Section I, both the rate of rise of $\mathrm{pH}$ and the absolute values achieved during the first 2 hours of life were similar. In addition, the healthy infants exposed to a cool environment at 2 hours of age showed very little, if any, change in $\mathrm{pH}$. Analysis of base deficit data, however, revealed the presence of metabolic acidosis in all infants subjected to cold stress. In addition there was concomitant 
reduction in $\mathrm{PCO}_{2}$, probably on a compensatory basis. This respiratory compensation for metabolic acidosis was complete in all high score infants irrespective of whether they were exposed to a cool environment immediately after delivery or at the age of 2 hours. The ratio of lactate to pyruvate in these infants remained relatively constant when they were transferred from a warm to a cool environment, suggesting that the rise in oxygen consumption during cold stress was not associated with a persistent oxygen debt.

The biochemical changes induced by cold stress in the four depressed infants differed from those seen in the healthy ones in several respects, namely, fall in $\mathrm{pH}$, greater increase in base deficit, smaller increase in oxygen consumption, and increased lactate to pyruvate ratio. These observations suggest an inadequate circulatory and respiratory response to cold stress. There was a partial respiratory compensation. In two infants in whom base deficit exceeded $10 \mathrm{mEq}$ per $\mathrm{L}$, $\mathrm{PCO}_{2}$ was lowered to $25 \mathrm{~mm} \mathrm{Hg}$. Had alveolar ventilation been impaired by prematurity, aspiration of meconium, or depression of the respiratory center, or had there been disturbances in ventilation perfusion ratio as a result of intrapulmonary or intracardiac shunts, it is unlikely that such a compensatory reduction in $\mathrm{PCO}_{2}$ could have occurred. In this event there would have been an even greater fall in $\mathrm{pH}$ during exposure to a cool environment. Even if elimination of $\mathrm{CO}_{2}$ in the depressed newborn were adequate, it is doubtful that cardiac output could be sufficiently increased to satisfy the greater demand for oxygen under conditions of lowered environmental temperature. Although it is obvious that no statistical conclusions can be drawn from the small number of depressed infants, there was a consistent fall in $\mathrm{pH}$ in the cool environment. Also, the increase in base deficit in every instance was greater than the mean change in the healthy infants by at least twice the standard error of the mean.

An identical hydrogen ion concentration at two different temperatures does not indicate the same acid-base environment. Because of changes in the dissociation constant of water, the neutrality point shifts approximately $0.05 \mathrm{pH}$ upward when temperature is lowered from $38^{\circ} \mathrm{C}$ to $35^{\circ}$ C. It is not yet known whether homeostatic mechanisms regulate towards a constant $\mathrm{pH}$ or a constant alkaline departure from neutrality. The body maintains a constant $\mathrm{pH}$ at normal body temperatures which is $0.6 \mathrm{pH}$ on the alkaline side of the neutrality point for water (6.8 at $38^{\circ} \mathrm{C}$ ). If the body temperature is lowered and the $\mathrm{pH}$ remains constant, then the degree of shift towards the alkaline side becomes less. In this sense, even the vigorous infants in the present study were less alkaline at lower body temperatures. If blood, in vivo, behaves similarly to that in vitro, then the $\mathrm{pH}$ would be expected to rise at lower temperatures.

The blood of hibernating bats, in vivo, does behave in this way, the $\mathrm{pH}$ at $8^{\circ} \mathrm{C}$ being 7.67 as compared with 7.40 at $38^{\circ} \mathrm{C}(20)$. It might be inferred from this that the normal $\mathrm{pH}$ at lower body temperatures is higher than 7.4; however, since hypothermia is an unnatural state for humans, it is at present not possible to define the ideal acid-base environment at lower body temperatures.

From a quantitative point of view these considerations are probably insignificant over the comparatively small temperature range in this study. They might, however, be of importance under conditions of deep hypothermia.

\section{Summary}

In mature newborn infants, recovery from birth asphyxia was influenced by the cold stress of normal room temperature. Under these conditions vigorous infants were able to achieve and maintain a relatively normal $\mathrm{pH}$. This was accomplished by increasing $\mathrm{CO}_{2}$ elimination to compensate for a developing metabolic acidosis.

Infants depressed for even a brief period at birth were unable to maintain their $\mathrm{pH}$ and developed a more pronounced metabolic acidosis in the cold environment.

\section{Acknowledgments}

We wish to express our appreciation to Mrs. L. Grann and Dr. S. S. Daniel for their invaluable assistance.

\section{References}

1. James, L. S., I. M. Weisbrot, C. E. Prince, D. A. Holaday, and V. Apgar. The acid-base status of human infants in relation to birth asphyxia and the onset of respiration. J. Pediat. 1958, 52, 379. 
2. James, L. S. Acidosis of the newborn and its relation to birth asphyxia. Acta Paediat. (Uppsala) 1960, 122 (suppl.), 17.

3. Apgar, V., D. A. Holaday, L. S. James, I. M. Weisbrot and C. Berrien. Evaluation of the newborn infant-second report. J. Amer. med. Ass. 1958, 168, 1985.

4. Siggaard Andersen, O., K. Engel, K. Jфrgensen, and P. Astrup. A micro method for determination of $\mathrm{pH}$, carbon dioxide tension, base excess and standard bicarbonate in capillary blood. Scand. J. clin. Lab. Invest. 1960, 12, 172.

5. Astrup, P., O. Siggaard Andersen, K. Jørgensen, and K. Engel. The acid-base metabolism. A new approach. Lancet 1960, 1, 1035.

6. Siggaard Andersen, O., and K. Engel. A new acidbase nomogram. An improved method for the calculation of the relevant blood acid-base data. Scand. J. clin. Lab. Invest. 1960, 12, 177.

7. Rosenthal, T. B. The effect of temperature on the $\mathrm{pH}$ of blood and plasma in vitro. J. biol. Chem. 1948, 173, 25.

8. Bradley, A. F., M. Stupfel, and J. W. Severinghaus. Effect of temperature on $\mathrm{PCO}_{2}$ and $\mathrm{Po}_{2}$ of blood in vitro. J. appl. Physiol. 1956, 9, 201.

9. Singer, R. B., and A. B. Hastings. An improved clinical method for the estimation of disturbances of the acid-base balance of human blood. Medicine (Baltimore) 1948, 27, 223.

10. Barker, S. B., and W. H. Summerson. The colorimetric determination of lactic acid in biological material. J. biol. Chem. 1941, 138, 535.
11. Friedemann, T. E., and G. E. Haugen. Pyruvic acid II. The determination of keto acids in blood and urine. J. biol. Chem. 1943, 147, 415.

12. McClure, J. H., and W. L. Caton. Normal temperature. I. Temperatures of term normal infants. J. Pediat. 1955, 47, 583.

13. Brück, K., M. Brück, and H. Lemtis. Hautdurchblutung und Thermoregulation beim Neugeborenen Kindern. Pflügers Arch. ges. Physiol. 1957, 265, 55.

14. Brück, $K$. Temperature regulation in the newborn infant. Biol. Neonat. 1961, 3, 65.

15. Hill, J. R. The oxygen consumption of new-born and adult mammals. Its dependence on the oxygen tension in the inspired air and on the environmental temperature. J. Physiol. (Lond.) 1959, 149, 346.

16. Adamsons, K., Jr. Breathing and the thermal environment in young rabbits. J. Physiol. (Lond.) 1959, 149, 144.

17. Stupfel, M. Action du Gas Carbonique sur la Thermoregulation, Etude Expérimentale chez le Rat Blanc. Paris, Jouve, 1959.

18. Von Euler, C., and U. Söderberg. Co-ordinated changes in temperature thresholds for thermoregulatory reflexes. Acta physiol. scand. 1958, $42,112$.

19. Mott, J. C. Quoted by G. S. Dawes in Somatic Stability in the Newly Born. Boston, Little, Brown, 1961, p. 177.

20. Siggaard Anderson, O., and W. Egsbaek. The influence of hypothermia on the acid-base status of hibernating bats. Ugeskr. Læg. 1962, 124, 929. 